\title{
Structural Investigations of Benzocyclopentadienylzinc Compounds. Crystal Structure of the Bis(tetrahydrofuran) Complex of Difluorenylzinc
}

\author{
Bart Fischer, Jaap Boersma, ${ }^{*}$ and Gerard van Koten \\ Department of Metal-Mediated Synthesis, Laboratory for Organic Chemistry, University of Utrecht, Padualaan 8 , \\ $3584 \mathrm{CH}$ Utrecht, The Netherlands
}

Wilberth J. J. Smeets and Anthony L. Spek

Vakgroep Algemene Chemie, Afdeling Kristal- en Structuurchemie, University of Utrecht, Padualaan 8 , $3584 \mathrm{CH}$ Utrecht, The Netherlands

Received June 6, 1988

\begin{abstract}
Crystals of difluorenylzinc-bis(tetrahydrofuran) are monoclinic, space group $P c$, with unit cell dimensions $a=9.680$ (2) $\AA, b=9.315$ (3) $\AA, c=16.061$ (4) $\AA, \beta=106.35(2)^{\circ}$, and $Z=2$. The structure refinement converged at $R_{F}=0.0426$. The crystal structure of the difluorenylzinc-tetrahydrofuran complex shows one of the first examples of a structurally characterized, $\eta^{1}$ metal-bonded fluorenyl group. Solution NMR data of the complex suggest a covalent bonding mode of the fluorenyl ligands and show the presence of two conformational isomers. From the crystal data it can be concluded that one of the two fluorenyl ligands is covalently bonded. The other ligand, however, shows some unexpected bonding features that probably do not result from crystal packing effects alone but may arise from electrostatic interactions that are also present in solid benzene and other aromatic compounds.
\end{abstract}

\section{Introduction}

The introduction of a benzo substituent onto a cyclopentadienyl system results in an indenyl group and has profound effects on the properties of the five-membered ring when it functions as a ligand bonded to a main group or transition metal. In particular, the $\eta^{5}$ to $\eta^{3}$ hapticity change is made much easier, and this well-documented change has become known as the indenyl effect. ${ }^{1}$ Compared to the indenyl group, the fluorenyl group, which can be considered as a dibenzocyclopentadienyl system, has attracted relatively little attention from coordination chemists. In fact, only eight crystal structure determinations have been carried out on fluorenylmetal compounds in the last 30 years. The fluorenyl ligand in these structures exhibits a variety of bonding modes, including $\eta^{3}$ in fluorenylbis (quinuclidine) lithium, ${ }^{2} \eta^{5}$ in fluorenyl(tetramethylethylenediamine)potassium, ${ }^{3}$ and $i^{6}$ in cyclopentadienylfluorenyliron. ${ }^{4}$ Until very recently, when Struchkov et al. published the structure of fluorenyl(triphenylphosphine)gold(I), ${ }^{5}$ no $\eta^{1}$-bonded fluorenyl ring was structurally characterized.

In our current studies on group 12 cyclopentadienyl compounds, we found, both in the gas phase as well as in the solid state, examples of $\eta^{1}$ coordination of a cyclopentadienyl group to zinc, ${ }^{6,7}$ cadmium, ${ }^{8,9}$ and mercury. ${ }^{10}$

(1) (a) Hart-Davis, A. J.; Mawby, R. J. J. Chem. Soc. A 1969, 2403. (b) Hart-Davis, A. J.; White, C.; Mawby, R. J. Inorg. Chim. Acta 1970, 4, 441 (c) White, C.; Mawby, R. J. Ibid. 1970, 4, 261. (d) Jones, D. J.; Mawby, R. J. Ibid. 1972, 6, 157. (e) Eshtiagh-Hosseini, H.; Nixon, F. J. J. LessCommon Met. 1978, 61, 107. (f) Rerek, M. E.; Ji, L.-N.; Basolo, F. J. Chem. Soc., Chem. Commun. 1983, 1208. (g) Ji, L.-N.; Rerek, M. E.; Basolo, F. Organometallics $1984,4,740$.

(2) Brooks, J. J.; Rhine, W.; Stucky, G. D. J. Am. Chem. Soc. 1972, 94, 7339

(3) Zerger, R.; Rhine, W.; Stucky, G. D. J. Am. Chem. Soc. 1974, 96 1441

(4) Johnson, J. W.; Treichel, P. M. J. Am. Chem. Soc. 1977, 99, 1427.

(5) Struchkov, Yu. T.; Slovokhotov, Yu. L.; Kravtsov, D. N.; Baukova, T. V.; Perevalova, E. G.; Grandberg, K. J. J. Organomet. Chem. 1988, 338, 269 .

(6) Budzelaar, P. H. M.; Boersma, J.; van der Kerk, G. J. M.; Spek,

A. L. Duisenberg A. J. M. J Organomet Chem 1985, 281, 123

(7) Blom, R.; Boersma, J.; Budzelaar, P. H. M.; Fischer, B.; Haaland A.; Volden, H. V.; Weidlein, W. Acta Chem. Scand. 1986, A40, 113.
We believe that in solutions of polar organic solvents the zinc and cadmium compounds also are twice $\eta^{1}$ coordinated. The metals acquire their octet of electrons in this case by accepting four additional electrons from coordinating solvent molecules.

In order to investigate the possibility of $\eta^{1}$ coordination of a fluorenyl group to a group 12 metal and to study a, so far not structurally characterized, coordination complex of a cyclopentadienylzinc compound, we prepared difluorenylzinc and determined the crystal structure of its tetrahydrofuran (THF) complex.

\section{Experimental Section}

All experiments were carried out in an atmosphere of dry, oxygen-free nitrogen by using standard Schlenk techniques. All solvents were dried and distilled from sodium benzophenone ketyl prior to use. NMR spectra were recorded on a Bruker AC 200P spectrometer. Dicyclopentadienylzinc was prepared as published earlier. ${ }^{6}$

Diindenylzinc. To a suspension of $5 \mathrm{~g}(118 \mathrm{mmol})$ of finely dispersed potassium in $100 \mathrm{~mL}$ of THF was slowly added 11.49 $\mathrm{mL}$ ( $100 \mathrm{mmol}$ ) of indene dissolved in $50 \mathrm{~mL}$ of THF. After being stirred for $6 \mathrm{~h}$, the yellow solution was decanted from the excess potassium and dried in vacuo to yield $15.12 \mathrm{~g} \mathrm{(98} \mathrm{\textrm {mmol } , 9 8 \% )}$ of pure, pale yellow indenylpotassium.

To a solution of $9 \mathrm{~g}(58.3 \mathrm{mmol})$ of indenylpotassium in 100 $\mathrm{mL}$ of THF was added $25.8 \mathrm{~mL}$ of a $1.13 \mathrm{M}$ solution of dry zinc chloride in diethyl ether. After the solution was stirred for $2 \mathrm{~h}$ the potassium chloride was removed by means of centrifugation and washed twice with $30 \mathrm{~mL}$ of THF. The combined THF solutions were evaporated to dryness. Heating of the solid residue to $70^{\circ} \mathrm{C}$ at $0.1 \mathrm{mmHg}$ yielded the pure, solvent-free, diindenylzinc in near quantative yield $(8.7 \mathrm{~g})$ as a pale yellow solid.

Difluorenylzinc. Difluorenylzinc was prepared in essentially the same way as diindenylzinc. Sodium hydride was used instead of potassium metal to prepare the fluorenyl anion. The pale yellow difluorenylzinc was also obtained in near quantative yield, and

(8) Fischer, B.; van Mier, G. P. M.; Boersma, J.; Smeets, W. J. J.; Spek, A. L. J. Organomet. Chem. 1987, 322, C37.

(9) Smeets, W. J. J.; Spek, A. L.; Fischer, B.; van Mier, G. P. M. Boersma, J. Acta Crystallogr. 1987, C43, 893.

(10) Fischer, B.; van Mier, G. P. M.; Boersma, J.; van Koten, G.; Smeets, W. J. J.; Spek, A. L. Recl. Trav. Chim. Pays-Bas 1988, 107, 259. 
Table I. Crystal Data and Details of the Structure Determination

$\begin{array}{ll} & \text { (a) Crystal Data } \\ \text { formula } & \mathrm{C}_{34} \mathrm{H}_{34} \mathrm{O}_{2} \mathrm{Zn} \\ \text { mol wt } & 540.02 \\ \text { cryst system } & \text { monoclinic } \\ \text { space group } & P_{c}(\text { No. } 7) \\ a, b, c(\AA) & 9.680(2), 9.315(3), 16.061(4) \\ \beta(\mathrm{deg}) & 106.35(2) \\ V\left(\AA^{3}\right) & 1389.7(7) \\ Z & 2 \\ D_{\text {calc }}\left(\mathrm{g} \mathrm{cm}^{-3}\right) & 1.290 \\ F(000) & 568 \\ \mu(\mathrm{Cu} \mathrm{K})\left(\mathrm{cm}^{-1}\right) & 14.3 \\ \text { cryst size }(\mathrm{mm}) & 0.68 \times 0.30 \times 0.25\end{array}$

$\theta_{\min }, \theta_{\max }(\mathrm{deg})$

radiatn

(b) Data Collection

$\omega / 2 \theta$ scan (deg) $2.9,70.0$

$\mathrm{Cu} \mathrm{K} \alpha$ (Ni-filtered), $1.54184 \AA$ $0.55+0.15 \tan \theta$

horizontal and vert aperture

$3.0,5.0$ (mm)

dist cryst to detector $(\mathrm{mm})$

ref reflectns $\quad 1 \overline{1} \overline{3} ; 0 \overline{1} 3$

total data $\quad 5654$

total unique data $\quad 5270$

obsd data $(I>2.5 \sigma(I)) \quad 3266$

\begin{tabular}{ll}
\multicolumn{2}{c}{ (c) Refinement } \\
no. of refined parameters & 339 \\
weighting scheme & $w=1.0 /\left[\sigma^{2}(F)+0.000362 F^{2}\right]$ \\
final $R$, w $R, S$ & $0.0426,0.0469,0.76$ \\
$(\Delta / \sigma)_{\max }$ in final cycle & 0.044 \\
min and max resd dens $\left(\mathrm{e} / \AA^{3}\right)$ & $-0.45,0.42$
\end{tabular}

its THF complex can be obtained in crystalline form by slow cooling of a saturated, warm THF solution. Anal. Calcd for $\mathrm{Zn}\left(\mathrm{C}_{13} \mathrm{H}_{9}\right)_{2}(\mathrm{THF})_{2}: \mathrm{Zn}, 12.11 ; \mathrm{C}, 75.62 ; \mathrm{H}, 6.35$. Found: $\mathrm{Zn}, 12.12$; $\mathrm{C}, 74.44 ; \mathrm{H}, 6.22$.

Structure Determination and Refinement of $\mathrm{Zn}\left(\mathrm{C}_{13^{-}}\right.$ $\left.\mathrm{H}_{9}\right)_{2}(\mathrm{THF})_{2}$. A colorless rod-shaped crystal suitable for an X-ray structure determination was mounted under nitrogen in a Lindemann glass capillary and transferred to an Enraf-Nonius CAD $-4 \mathrm{~F}$ diffractometer for data collection. Crystal data and details of the structure determination are given in Table I. Unit cell parameters were determined from a least-squares treatment of the setting angles of 12 reflections in the range $9.7 \leq \theta \leq 14.8^{\circ}$. The monoclinic unit cell was checked for the presence of higher lattice symmetry. ${ }^{11}$ Data were collected for two Bijvoet-related quadrants: $h k l$ and $\bar{h} k \bar{l}(-11 \leq h \leq 11 ;-11 \leq k \leq 0 ;-19 \leq l \leq$ 19 ) and corrected for $L p$ and a linear decay of $3.8 \%$ during the $96 \mathrm{~h}$ of X-ray exposure time. Standard deviations as obtained by counting statistics were increased according to an analysis of the excess variance of the three reference reflections: $\sigma^{2}(I)=$ $\sigma^{2}{ }_{\mathrm{CS}}(I)+(0.014)^{2} .12$ Space group $P c$ was determined from the systematic extinctions $h 0 l, l=2 n+1$, and discriminated from $P 2 / c$ during the structure determination process. The structure was solved with direct methods (SHELXS86), ${ }^{13}$ the solution with the best figure of merit showed the zinc atoms and most of the carbon and oxygen atoms. The remaining non-hydrogen atoms were located from subsequent difference Fourier maps. Refinement on $F$ was carried out by full-matrix least-squares techniques. All non-hydrogens atoms were refined with anisotropic thermal parameters. The hydrogen atoms of the zinc-bonded $C(1)$ and $C(14)$ atoms were located from a difference Fourier map and refined with slack constraints. The remaining $\mathrm{H}$ atoms were introduced on calculated positions $(\mathrm{C}-\mathrm{H}=0.98 \AA)$ and included in the refinement riding on their carrier atom. All hydrogen atoms were refined with one common isotropic thermal parameter. Weights were introduced in the final refinement cycles; convergence was reached at $R=0.0426$. The absolute structure was

(11) Le Page, Y. J. Appl. Crystallogr. 1982, 15, 255.

(12) McCandlish, L. E.; Stout, G. H.; Andrews, L. C. Acta Crystallogr. 1975, A31, 245

(13) Sheldrick, G. M. SHELXS86, Program for Crystal Structure Determination; University of Göttingen: Göttingen, Federal Republic of Germany, 1986 .
Table II. Fractional Atomic Coordinates and Equivalent Isotropic Thermal Parameters with Esd's in Parentheses for $\mathrm{Zn}\left(\mathrm{C}_{13} \mathrm{H}_{9}\right)_{2}(\mathrm{THF})_{2}$

\begin{tabular}{|c|c|c|c|c|}
\hline & $x$ & $y$ & $z$ & $U_{\mathrm{eq}}{ }^{a} \AA^{2}$ \\
\hline $\mathrm{Zn}$ & $0.5031(\ldots)$ & $0.00032(9)$ & $0.3246(\ldots)$ & $0.0569(2)$ \\
\hline$O(1)$ & $0.6566(5)$ & $-0.1411(4)$ & $0.2985(3)$ & $0.081(2)$ \\
\hline $\mathrm{O}(2)$ & $0.3393(5)$ & $-0.1166(5)$ & $0.2381(2)$ & $0.087(2)$ \\
\hline $\mathrm{C}(1)$ & $0.4914(6)$ & $0.0030(7)$ & 0.4495 (3) & $0.060(2)$ \\
\hline $\mathrm{C}(2)$ & $0.3582(6)$ & $-0.0643(6)$ & $0.4577(3)$ & $0.054(2)$ \\
\hline $\mathrm{C}(3)$ & $0.2164(7)$ & $-0.0217(8)$ & $0.4243(4)$ & $0.075(2)$ \\
\hline $\mathrm{C}(4)$ & $0.1084(8)$ & $-0.104(1)$ & $0.4410(4)$ & $0.090(3)$ \\
\hline $\mathrm{C}(5)$ & $0.1395(8)$ & $-0.2272(9)$ & $0.4885(5)$ & $0.083(3)$ \\
\hline $\mathrm{C}(6)$ & $0.2811(8)$ & $-0.2735(7)$ & $0.5231(4)$ & $0.070(3)$ \\
\hline$C(7)$ & $0.3927(6)$ & $-0.1908(6)$ & $0.5084(3)$ & $0.052(2)$ \\
\hline $\mathrm{C}(8)$ & $0.5474(6)$ & $-0.2044(6)$ & $0.5386(3)$ & $0.058(2)$ \\
\hline $\mathrm{C}(9)$ & $0.6322(7)$ & $-0.3076(7)$ & $0.5915(3)$ & $0.072(3)$ \\
\hline $\mathrm{C}(10)$ & 0.780 & $-0.288(1)$ & $0.6152(4)$ & 0.096 \\
\hline $\mathrm{C}(11)$ & $0.8385(8)$ & $-0.171(1)$ & $0.5871(5)$ & $0.105(4)$ \\
\hline $\mathrm{C}(12)$ & $0.7543(8)$ & $-0.068(1)$ & $0.5322(4)$ & $0.087(3)$ \\
\hline $\mathrm{C}(13)$ & $0.6057(6)$ & $-0.0836(7)$ & $0.5065(3)$ & $0.060(2)$ \\
\hline $\mathrm{C}(14)$ & $0.5226(6)$ & $0.1939(6)$ & $0.2679(3)$ & $0.054(2)$ \\
\hline $\mathrm{C}(15)$ & $0.4048(6)$ & $0.2752(6)$ & $0.2878(3)$ & $0.051(2)$ \\
\hline$C(16)$ & $0.2568(7)$ & $0.2786(8)$ & $0.2491(4)$ & $0.072(3)$ \\
\hline $\mathrm{C}(17)$ & $0.1697(7)$ & $0.3562(8)$ & $0.2863(4)$ & $0.079(3)$ \\
\hline$C(18)$ & $0.2273(7)$ & 0.4371 & 0.3607 (4) & $0.071(2)$ \\
\hline$C(19)$ & $0.3712(7)$ & $0.4383(7)$ & $0.3995(4)$ & $0.064(2)$ \\
\hline$C(20)$ & $0.4617(6)$ & $0.3610(6)$ & $0.3627(3)$ & $0.055(2)$ \\
\hline $\mathrm{C}(21)$ & $0.6172(6)$ & $0.3442(6)$ & $0.3889(3)$ & $0.051(2)$ \\
\hline $\mathrm{C}(22)$ & $0.7232(7)$ & $0.4043(7)$ & $0.4569(4)$ & $0.067(2)$ \\
\hline $\mathrm{C}(23)$ & $0.8655(7)$ & $0.3770(8)$ & $0.4643(4)$ & $0.079(3)$ \\
\hline $\mathrm{C}(24)$ & $0.9012(7)$ & $0.2835(8)$ & $0.4065(4)$ & $0.077(3)$ \\
\hline$C(25)$ & $0.7981(7)$ & $0.2229(7)$ & $0.3378(4)$ & $0.069(2)$ \\
\hline $\mathrm{C}(26)$ & $0.6529(7)$ & $0.2498(6)$ & $0.3292(3)$ & $0.055(2)$ \\
\hline $\mathrm{C}(27)$ & $0.6922(9)$ & $-0.2783(8)$ & $0.3371(5)$ & 0.088 \\
\hline $\mathrm{C}(28)$ & $0.754(1)$ & $-0.359(1)$ & $0.2774(6)$ & $0.155(6)$ \\
\hline $\mathrm{C}(29)$ & $0.746(1)$ & $-0.272(1)$ & $0.2038(7)$ & $0.164(6)$ \\
\hline $\mathrm{C}(30)$ & 0.704 (I) & $-0.131(1)$ & $0.2219(5)$ & 0.122 \\
\hline $\mathrm{C}(31)$ & 0.279 (1) & $-0.2473(9)$ & $0.2569(5)$ & 0.110 \\
\hline $\mathrm{C}(32)$ & $0.211(2)$ & $-0.313(1)$ & $0.1764(7)$ & $0.227(8)$ \\
\hline $\mathrm{C}(33)$ & $0.227(2)$ & $-0.219(1)$ & $0.1080(6)$ & $0.206(7)$ \\
\hline $\mathrm{C}(34)$ & $0.292(1)$ & $-0.095(1)$ & $0.1464(5)$ & $0.144(5)$ \\
\hline
\end{tabular}

${ }^{a} U_{\mathrm{eq}}=1 / 3 \sum_{i} \sum_{j} U_{i j} a_{i} * a_{j}^{*} a_{i} \cdot a_{j}$.

checked by refinement with either $+i f^{\prime}$ or $-i f^{\prime \prime}$. The alternative configuration was rejected, based on its higher $R$ values: $R=$ 0.0458 and $w R=0.0518$.

Final atomic coordinates and equivalent isotropic thermal parameters are listed in Table II. Neutral atom scattering factors were taken from ref 14 and are corrected for anomalous dispersion. ${ }^{15}$ Data collection was done with a modified CAD-4F software package $^{16}$ All calculations were performed with SHELX $76^{17}$ and the EUCLID package ${ }^{18}$ (geometrical calculations and illustrations) on a MicroVAX-II computer.

\section{Results and Discussion}

Synthesis. Difluorenylzinc was obtained from the reaction of fluorenylsodium, prepared from fluorene and sodium hydride in THF, with $1 / 2$ equiv of dry zinc dichloride in a tetrahydrofuran/diethyl ether mixture.

Difluorenylzinc is a moisture- and air-sensitive, pale yellow solid, which is thermally stable up to $210^{\circ} \mathrm{C}$. Its volatility at temperatures below $200^{\circ} \mathrm{C}$ is too low to allow vacuum sublimation. It is insoluble in apolar and weakly polar organic solvents but dissolves well in polar organic solvents like THF, DMSO, and pyridine from which it inevitably recrystallizes in a solvated form. It can be ob-

(14) Cromer, D. T.; Mann, J. B. Acta Crystallogr. 1968, A24, 321. (15) Cromer, D. T.; Liberman, D. J. Chem. Phys. 1970, 53, 1891 C 410 .

16) De Boer, J. L.; Duisenberg, A. J. M. Acta Crystallogr. 1984, A40,

(17) Sheldrick, G. M. SHELX76, Crystal Analysis Package; University of Cambridge: Cambridge, England, 1976

(18) Spek, A. L. The EUCLID Package. In Computational Crystallography; Sayre, D., Ed.; Clarendon Press: Oxford, 1982. 
Table III. ' $\mathrm{H}$ and ${ }^{13} \mathrm{C}$ NMR Data for $\mathrm{Zn}\left(\mathrm{C}_{5} \mathrm{H}_{5}\right)_{2}, \mathrm{Zn}\left(\mathrm{C}_{9} \mathrm{H}_{7}\right)_{2}, \mathrm{~K}\left(\mathrm{C}_{9} \mathrm{H}_{7}\right), \mathrm{Zn}\left(\mathrm{C}_{13} \mathrm{H}_{9}\right)_{2}$, and $\mathrm{Na}\left(\mathrm{C}_{13} \mathrm{H}_{9}\right)^{a}$

\begin{tabular}{|c|c|c|c|c|c|c|c|c|}
\hline \multirow[t]{2}{*}{ Complex } & \multirow{2}{*}{$\frac{\delta^{1} \mathrm{H}}{\mathrm{H} 1}$} & \multicolumn{7}{|c|}{$\delta^{13} \mathrm{C},\left({ }^{1} \mathrm{~J}_{\mathrm{C}-\mathrm{H}}\right)$} \\
\hline & & $\mathrm{C}_{1}$ & $\mathrm{C} 2$ & $\mathrm{C} 3$ & $\mathrm{C} 4$ & $\mathrm{C} 5$ & $\mathrm{C} 6$ & $\mathrm{Cl}$ \\
\hline & 5.78 & $\begin{array}{l}107.5^{b} \\
(160)\end{array}$ & - & - & - & - & - & - \\
\hline & $5.29 \mathrm{C}$ & $\begin{array}{l}83.8 \\
(161)\end{array}$ & $\begin{array}{l}133.4 \\
(153)\end{array}$ & $\begin{array}{l}142.3 \\
(-)\end{array}$ & $\begin{array}{l}119.8 \\
(156)\end{array}$ & $\begin{array}{l}118.9 \\
(154)\end{array}$ & - & - \\
\hline & $5.70^{d}$ & $\begin{array}{l}92.4 \\
(160)\end{array}$ & $\begin{array}{l}116.6 \\
(154)\end{array}$ & $\begin{array}{l}127.6 \\
(-)\end{array}$ & $\begin{array}{l}117.9 \\
(153)\end{array}$ & $\begin{array}{l}112.4 \\
(154)\end{array}$ & . & - \\
\hline & $4.45,4.30^{e}$ & $\begin{array}{l}44.0 \\
(138)\end{array}$ & $\begin{array}{l}150.2 \\
(-)\end{array}$ & $\begin{array}{l}123.9 \\
(157)\end{array}$ & $\begin{array}{l}121.1 \\
(156)\end{array}$ & $\begin{array}{l}119.9 \\
(158)\end{array}$ & $\begin{array}{l}118.9 \\
(155)\end{array}$ & $\begin{array}{l}135.8 \\
(-)\end{array}$ \\
\hline & 5.52 & $\begin{array}{l}79.5 \\
(161)\end{array}$ & $\begin{array}{l}135.5 \\
(-)\end{array}$ & $\begin{array}{l}119.2 \\
(153)\end{array}$ & $\begin{array}{l}118.4 \\
(150)\end{array}$ & $\begin{array}{l}115.7 \\
(151)\end{array}$ & $\begin{array}{l}108.6 \\
(156)\end{array}$ & $\begin{array}{l}120.8 \\
(-)\end{array}$ \\
\hline
\end{tabular}

${ }^{a}$ Measured in THF- $d_{8}$ at $200 \mathrm{MHz}$ at $293 \mathrm{~K} \delta$ in ppm relative to external TMS, $J$ in $\mathrm{Hz}$; assignments were based on other known indenyl and fluorenyl compounds. ${ }^{b}$ All carbons occur as one singlet. ${ }^{c}$ Chemical shifts of protons 2,4 , and 5: $6.72,6.85$, and 7.32 ppm, respectively. ${ }^{d}$ Chemical shifts of protons, 2,4 , and 5: $6.31,6.34$, and $7.16 \mathrm{ppm}$, respectively. ${ }^{e}$ Other protons occur as a complex multiplet between 7 and 8 ppm.

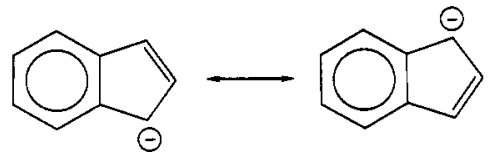

Figure 1. Resonance forms of the indenyl ion.

tained in the solvent-free form by heating to $150^{\circ} \mathrm{C}$ in high vacuum. In this form the structure probably consists of a coordination polymer like was found for $\mathrm{Zn}\left(\mathrm{C}_{5} \mathrm{H}_{5}\right)_{2}{ }^{6}$

We have been able, so far, only to obtain single crystals of the bis(tetrahydrofuran) complex.

NMR and Solution Structure. To gain information about the character of the zinc-carbon interaction in difluorenylzinc in solution, its NMR data were compared to those of dicyclopentadienylzinc and diindenylzinc as well as to those of the ionic compounds indenylpotassium and fluorenylsodium. ${ }^{1} \mathrm{H}$ and ${ }^{13} \mathrm{C}$ NMR spectra of all compounds have been measured in THF- $d_{8}$ at room temperature, and these data are collected in Table III.

Looking first at dicyclopentadienylzinc one finds that both the ${ }^{1} \mathrm{H}$ NMR and ${ }^{13} \mathrm{C}$ NMR spectra show a single sharp peak that can be accounted for by consecutive 1,3 shifts which are fast on the NMR time scale. ${ }^{19}$ For this compound the ${ }^{1} J_{\mathrm{C}-\mathrm{H}}$ coupling constant and the ${ }^{1} \mathrm{H}$ and ${ }^{13} \mathrm{C}$ chemical shifts are in accord with the presence of an aromatic five-membered ring with $\mathrm{sp}^{2}$-hybridized carbon atoms and a negative charge that is fully delocalized over the ring. We believe that the metal-ring interaction is comparable to that in dicyclopentadienylcadmium and thus ionic in character. ${ }^{8,9}$

It is clear that in the case of diindenylzinc, the presence of a fused six-membered ring in the indenyl ligand will have considerable influence on the delocalization of the (partial) negative charge. The reluctance of the benzene moiety to give up aromaticity leaves two resonance forms (Figure 1), the structures of which clearly illustrate why the indenyl ligand frequently adopts an $\eta^{3}$ or allylic bonding mode. In diindenylzinc the ${ }^{1} J_{\mathrm{C}-\mathrm{H}}$ as well as the chemical shift of the carbon atoms $\alpha$ to the benzene

(19) Lorberth, J. J. Organomet. Chem. 1969, 19, 189. fragment are smaller than those in dicyclopentadienylzinc. This can be understood in terms of more $\mathrm{sp}^{3}$ character of these $\alpha$-carbon atoms. In diindenylzinc there is a large difference between the chemical shift of the carbon atoms at the $\alpha$ - and $\beta$-positions. Similar trends are observed in the ${ }^{1} \mathrm{H}$ chemical shifts. Apparently, the negative charge is more or less localized on the carbon atoms $\alpha$ to the benzene fragment, and it is reasonable to assume that zinc will interact with these atoms. The $\beta$-carbon atom shows a downfield shift when compared to the carbon atoms in dicyclopentadienylzinc since it has olefinic character and does not, to a great extent, interact with the zinc atom. A similar argument was put forward by Hoffmann et al., ${ }^{20}$ who used ${ }^{1} \mathrm{H}$ and ${ }^{13} \mathrm{C}$ NMR chemical shifts to determine the $\eta^{1}$-bonding mode in allylzinc compounds. The trend toward a localized, covalent zinc-carbon interaction in diindenylzinc can also be seen from a comparison of the NMR data of the latter with those of indenylpotassium, in which the metal-carbon interaction is ionic ${ }^{21}$ and therefore the chemical shifts of the $\alpha$ - and $\beta$-carbon atoms differ only little and the $\alpha$-carbon atom is found at a lower field. The other carbon atoms of diindenylzinc are found between 118.9 and $142.3 \mathrm{ppm}$.

A comparison of ${ }^{1} J_{\mathrm{C}-\mathrm{H}}$ and the ${ }^{13} \mathrm{C}$ chemical shift of the bridgehead carbon of difluorenylzinc with that of fluorene $(130 \mathrm{~Hz}, 36.17 \mathrm{ppm})$ and of fluorenylsodium, an established ionic compounds, ${ }^{2,21}$ shows that the bridgehead carbon atom in difluorenylzinc is $\mathbf{s p}^{3}$-hydridized and that the zinc-carbon interaction is of covalent character. These observations are consistent with considerable charge localization caused by the presence of two fused benzene moieties in the fluorenyl ligand. The other carbon atoms of difluorenylzinc are found between 118.9 and $150.2 \mathrm{ppm}$.

Interestingly, in the ${ }^{1} \mathrm{H}$ NMR spectrum of difluorenylzinc the protons at the bridgehead carbon atoms appear as two singlets with relative areas of $2: 1$ at 4.45 and 4.30 ppm, respectively, while the other protons are found as a

(20) Hoffmann, E. G.; Nehl, H.; Lehmkuhl, H.; Seevogel, R.; Stempfle, W. Chem. Ber. 1984, 117, 1364

(21) Grutzner, J. B.; Lawlar, J. M.; Jackman, L. M. J. Am. Chem. 1972, $98,2306$. 
Table IV. Relevant Data on the Geometry of $\mathrm{Zn}\left(\mathrm{C}_{13} \mathrm{H}_{\mathbf{9}}\right)_{2}$ (THF)

\begin{tabular}{|c|c|c|c|}
\hline \multicolumn{4}{|c|}{ (a) Bond Distances $(\AA)$} \\
\hline $\mathrm{Zn}-\mathrm{O}(1)$ & $2.114(5)$ & $C(12)-C(13)$ & $1.39(1)$ \\
\hline $\mathrm{Zn}-\mathrm{O}(2)$ & $2.095(4)$ & $\mathrm{C}(14)-\mathrm{C}(15)$ & $1.477(8)$ \\
\hline $\mathrm{Zn}-\mathrm{C}(1)$ & $2.041(5)$ & $\mathrm{C}(14)-\mathrm{C}(26)$ & $1.460(8)$ \\
\hline $\mathrm{Zn}-\mathrm{C}(14)$ & $2.053(6)$ & $\mathrm{C}(15)-\mathrm{C}(16)$ & $1.392(9)$ \\
\hline $\mathrm{O}(1)-\mathrm{C}(27)$ & $1.420(9)$ & $C(15)-C(20)$ & $1.420(7)$ \\
\hline $\mathrm{O}(1)-\mathrm{C}(30)$ & $1.43(1)$ & $\mathrm{C}(16)-\mathrm{C}(17)$ & 1.37 (1) \\
\hline $\mathrm{O}(2)-\mathrm{C}(31)$ & $1.42(1)$ & $C(17)-C(18)$ & $1.390(9)$ \\
\hline $\mathrm{O}(2)-\mathrm{C}(34)$ & $1.428(8)$ & $\mathrm{C}(18)-\mathrm{C}(19)$ & $1.36(1)$ \\
\hline $\mathrm{C}(1)-\mathrm{C}(2)$ & $1.473(9)$ & $C(19)-C(20)$ & $1.388(9)$ \\
\hline$C(1)-C(13)$ & $1.464(8)$ & $\mathrm{C}(20)-\mathrm{C}(21)$ & $1.453(8)$ \\
\hline$C(2)-C(3)$ & $1.384(9)$ & $\mathrm{C}(21)-\mathrm{C}(22)$ & $1.389(8)$ \\
\hline $\mathrm{C}(2)-\mathrm{C}(7)$ & $1.418(8)$ & $\mathrm{C}(21)-\mathrm{C}(26)$ & $1.414(8)$ \\
\hline$C(3)-C(4)$ & $1.38(1)$ & $\mathrm{C}(22)-\mathrm{C}(23)$ & $1.37(1)$ \\
\hline$C(4)-C(5)$ & $1.36(1)$ & $C(23)-C(24)$ & $1.39(1)$ \\
\hline$C(5)-C(6)$ & $1.39(1)$ & $C(24)-C(25)$ & $1.383(9)$ \\
\hline$C(6)-C(7)$ & $1.40(1)$ & $\mathrm{C}(25)-\mathrm{C}(26)$ & $1.40(1)$ \\
\hline$C(7)-C(8)$ & $1.444(8)$ & $\mathrm{C}(27)-\mathrm{C}(28)$ & $1.47(1)$ \\
\hline$C(8)-C(9)$ & $1.388(8)$ & $\mathrm{C}(28)-\mathrm{C}(29)$ & $1.42(1)$ \\
\hline $\mathrm{C}(8)-\mathrm{C}(13)$ & $1.419(8)$ & $\mathrm{C}(29)-\mathrm{C}(30)$ & $1.43(1)$ \\
\hline$C(9)-C(10)$ & $1.38(1)$ & $\mathrm{C}(31)-\mathrm{C}(32)$ & $1.42(1)$ \\
\hline $\mathrm{C}(10)-\mathrm{C}(11)$ & $1.37(1)$ & $\mathrm{C}(32)-\mathrm{C}(33)$ & $1.45(2)$ \\
\hline$C(11)-C(12)$ & $1.40(1)$ & $\mathrm{C}(33)-\mathrm{C}(34)$ & $1.37(2)$ \\
\hline \multicolumn{4}{|c|}{ (b) Bond Angles (deg) } \\
\hline $\mathrm{O}(1)-\mathrm{Zn}-\mathrm{O}(2)$ & $89.3(2)$ & $\mathrm{C}(1)-\mathrm{C}(13)-\mathrm{C}(12)$ & $131.7(6)$ \\
\hline $\mathrm{O}(1)-\mathrm{Zn}-\mathrm{C}(1)$ & $116.0(2)$ & $C(8)-C(13)-C(12)$ & $117.4(6)$ \\
\hline $\mathrm{O}(1) \mathrm{Zn}-\mathrm{C}(14)$ & $107.6(2)$ & $\mathrm{Zn}-\mathrm{C}(14)-\mathrm{C}(15)$ & $100.5(4)$ \\
\hline $\mathrm{O}(2)-\mathrm{Zn}-\mathrm{C}(1)$ & $114.7(2)$ & $\mathrm{Zn}-\mathrm{C}(14)-\mathrm{C}(26)$ & $100.6(3)$ \\
\hline $\mathrm{O}(2)-\mathrm{Zn}-\mathrm{C}(14)$ & $108.0(2)$ & $C(15)-C(14)-C(26)$ & $104.1(4)$ \\
\hline$C(1)-Z n-C(14)$ & $117.6(2)$ & $C(14)-C(15)-C(16)$ & $132.5(5)$ \\
\hline $\mathrm{Zn}-\mathrm{O}(1)-\mathrm{C}(27)$ & $124.9(5)$ & $\mathrm{C}(14)-\mathrm{C}(15)-\mathrm{C}(20)$ & $109.4(5)$ \\
\hline $\mathrm{Zn}-\mathrm{O}(1)-\mathrm{C}(30)$ & $122.9(5)$ & $C(16)-C(15)-C(20)$ & $118.1(5)$ \\
\hline $\mathrm{C}(27)-\mathrm{O}(1)-\mathrm{C}(30)$ & $109.7(6)$ & $C(15)-C(16)-C(17)$ & $120.0(6)$ \\
\hline $\mathrm{Zn}-\mathrm{O}(2)-\mathrm{C}(31)$ & $125.8(4)$ & $\mathrm{C}(16)-\mathrm{C}(17)-\mathrm{C}(18)$ & $120.9(6)$ \\
\hline $\mathrm{Zn}-\mathrm{O}(2)-\mathrm{C}(34)$ & $125.0(5)$ & $\mathrm{C}(17)-\mathrm{C}(18)-\mathrm{C}(19)$ & $120.7(6)$ \\
\hline $\mathrm{C}(31)-\mathrm{O}(2)-\mathrm{C}(34)$ & $107.9(6)$ & $\mathrm{C}(18)-\mathrm{C}(19)-\mathrm{C}(20)$ & $119.3(6)$ \\
\hline $\mathrm{Zn}-\mathrm{C}(1)-\mathrm{C}(2)$ & $112.0(3)$ & $C(15)-C(20)-C(19)$ & $120.8(5)$ \\
\hline $\mathrm{Zn}-\mathrm{C}(1)-\mathrm{C}(13)$ & $111.5(4)$ & $\mathrm{C}(15)-\mathrm{C}(20)-\mathrm{C}(21)$ & $107.9(5)$ \\
\hline $\mathrm{C}(2)-\mathrm{C}(1)-\mathrm{C}(13)$ & $103.7(5)$ & $\mathrm{C}(19)-\mathrm{C}(20)-\mathrm{C}(21)$ & $131.2(5)$ \\
\hline $\mathrm{C}(1)-\mathrm{C}(2)-\mathrm{C}(3)$ & $129.9(5)$ & $\mathrm{C}(20)-\mathrm{C}(21)-\mathrm{C}(22)$ & $131.3(5)$ \\
\hline$C(1)-C(2)-C(7)$ & $109.5(5)$ & $C(20)-C(21)-C(26)$ & $107.6(5)$ \\
\hline $\mathrm{C}(3)-\mathrm{C}(2)-\mathrm{C}(7)$ & $120.6(6)$ & $\mathrm{C}(22)-\mathrm{C}(21)-\mathrm{C}(26)$ & $121.1(6)$ \\
\hline $\mathrm{C}(2)-\mathrm{C}(3)-\mathrm{C}(4)$ & $119.1(6)$ & $\mathrm{C}(21)-\mathrm{C}(22)-\mathrm{C}(23)$ & $119.7(6)$ \\
\hline$C(3)-C(4)-C(5)$ & $121.1(7)$ & $\mathrm{C}(22)-\mathrm{C}(23)-\mathrm{C}(24)$ & $119.5(6)$ \\
\hline$C(4)-C(5)-C(6)$ & $121.4(7)$ & $\mathrm{C}(23)-\mathrm{C}(24)-\mathrm{C}(25)$ & $122.1(7)$ \\
\hline $\mathrm{C}(5)-\mathrm{C}(6)-\mathrm{C}(7)$ & $118.8(6)$ & $\mathrm{C}(24)-\mathrm{C}(25)-\mathrm{C}(26)$ & $119.1(6)$ \\
\hline $\mathrm{C}(2)-\mathrm{C}(7)-\mathrm{C}(6)$ & $119.1(6)$ & $\mathrm{C}(14)-\mathrm{C}(26)-\mathrm{C}(21)$ & $110.5(6)$ \\
\hline$C(2)-C(7)-C n 8)$ & $108.7(5)$ & $\mathrm{C}(14)-\mathrm{C}(26)-\mathrm{C}(25)$ & $131.1(5)$ \\
\hline$C(6)-C(7)-C(8)$ & $132.2(5)$ & $\mathrm{C}(21)-\mathrm{C}(26)-\mathrm{C}(25)$ & ) $118.4(5)$ \\
\hline $\mathrm{C}(7)-\mathrm{C}(8)-\mathrm{C}(9)$ & $130.2(6)$ & $\mathrm{O}(1)-\mathrm{C}(27)-\mathrm{C}(28)$ & $105.6(7)$ \\
\hline $\mathrm{C}(7)-\mathrm{C}(8)-\mathrm{C}(13)$ & $106.8(5)$ & $\mathrm{C}(27)-\mathrm{C}(28)-\mathrm{C}(29)$ & ) $108.5(9)$ \\
\hline $\mathrm{C}(9)-\mathrm{C}(8)-\mathrm{C}(13)$ & $123.0(6)$ & $\mathrm{C}(28)-\mathrm{C}(29)-\mathrm{C}(30)$ & $107.8(9)$ \\
\hline $\mathrm{C}(8)-\mathrm{C}(9)-\mathrm{C}(10)$ & $117.7(6)$ & $\mathrm{O}(1)-\mathrm{C}(30)-\mathrm{C}(29)$ & $107.0(8)$ \\
\hline $\mathrm{C}(9)-\mathrm{C}(10)-\mathrm{C}(11)$ & $120.5(8)$ & $\mathrm{O}(2)-\mathrm{C}(31)-\mathrm{C}(32)$ & $107.0(8)$ \\
\hline $\mathrm{C}(10)-\mathrm{C}(11)-\mathrm{C}(12)$ & $122.4(8)$ & $\mathrm{C}(31)-\mathrm{C}(32)-\mathrm{C}(33)$ & ) $108(1)$ \\
\hline $\mathrm{C}(11)-\mathrm{C}(12)-\mathrm{C}(13)$ & $119.1(8)$ & $\mathrm{C}(32)-\mathrm{C}(33)-\mathrm{C}(34)$ & $107.7(8)$ \\
\hline $\mathrm{C}(1)-\mathrm{C}(13)-\mathrm{C}(8)$ & $110.9(5)$ & $\mathrm{O}(2)-\mathrm{C}(34)-\mathrm{C}(33)$ & $108.7(8)$ \\
\hline
\end{tabular}

complex multiplet between 7 and $8 \mathrm{ppm}$. This feature points to the existence of two different conformational isomers in solution. The large size of the fluorenyl ligands will, in the $\eta^{1}$ case, hamper free rotation around the zinc-carbon bond and thus give rise to three possible isomers (Figure 2). Of these isomers, isomer 1 is very improbable due to severe steric repulsion of the two fluorenyl groups.

To determine which of the two remaining isomers is preferred in the solid state, we conducted a crystal structure study of the bis(tetrahydrofuran) solvate of difluorenylzinc, viz., $\mathrm{Zn}\left(\mathrm{C}_{13} \mathrm{H}_{9}\right)_{2}(\mathrm{THF})_{2}$.

Crystal Structure of $\mathrm{Zn}\left(\mathrm{C}_{13} \mathrm{H}_{9}\right)_{2}$ (THF) $)_{2}$. The crystal structure of the title compound consists of the packing of two discrete molecules in a monoclinic unit cell. Bond distances and bond angles are collected in Table IV. A
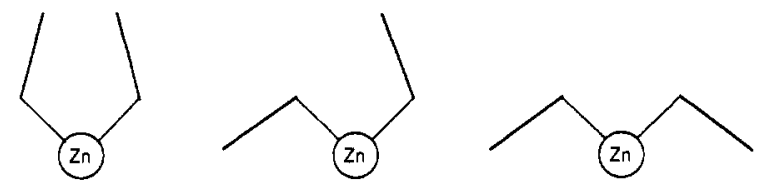

Figure 2. Possible isomers of difluorenylzinc in THF solution, viewed perpendicular to the plane determined by both zinc-carbon bonds. The coordinated THF molecules have been omitted.

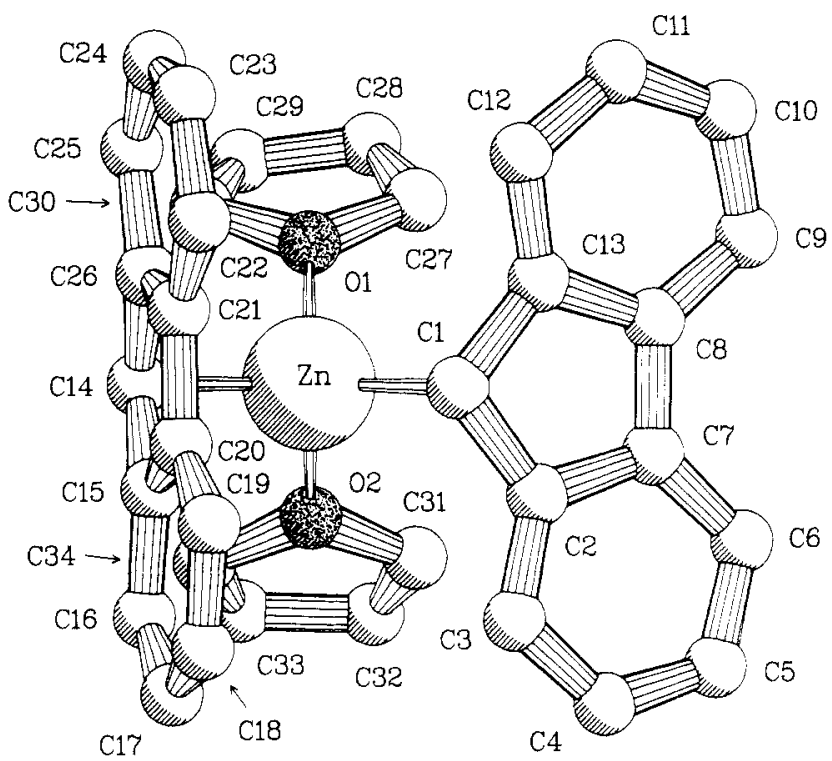

Figure 3. View of the molecular structure of difluorenylzincbis(tetrahydrofuran), with the adopted numbering. $H$ atoms have been omitted for clarity.

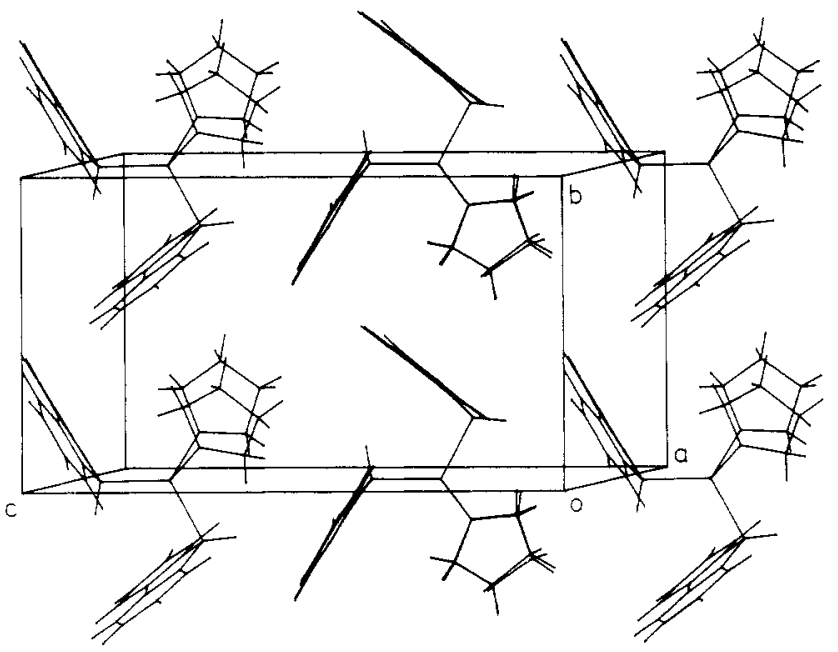

Figure 4. Drawing of the unit cell contents, showing the packing of the molecules and the orthogonality of the fluorenyl ligands.

perspective view of the molecule with the adopted atom numbering is presented in Figure 3 together with a view of the unit cell in Figure 4.

The crystal structure of the difluorenylzinc complex is unique for two reasons: first, it contains the first example of a structurally characterized, $\eta^{1}$ group 12 metal-bonded fluorenyl group, and second, it is the first structure of a coordination complex of a cyclopentadienylzinc compound.

In the title compound each zinc atom is surrounded pseudotetrahedrally by two $\eta^{1}$-bonded fluorenyl groups and two coordinated THF molecules with $\mathrm{C}-\mathrm{Zn}-\mathrm{C}$ and $\mathrm{O}-\mathrm{Zn}-\mathrm{O}$ angles of $117.6(2)$ and $89.3(2)^{\circ}$, respectively (see Figure 3). The $\mathrm{Zn}-\mathrm{O}$ distances are normal for coordinating THF, being 2.114 (5) and 2.095 (4) $\AA$. The $\mathrm{Zn}-\mathrm{C}$ distances 
Table V. Selected Bond Lengths and Bond Angles in Some Fluorenyl Compounds ${ }^{a}$

\begin{tabular}{ccccccc}
\hline & \multicolumn{5}{c}{ bond lengths $(\AA)$} \\
\cline { 2 - 7 } compd & ring & $\mathrm{C}(1)-\mathrm{C}(2) /$ & $\mathrm{C}(2)-\mathrm{C}(7) /$ & $\mathrm{C}(7)-\mathrm{C}(8) /$ & $\mathrm{C}(8)-\mathrm{C}(13) /$ & $\mathrm{C}(13)-\mathrm{C}(1) /$ \\
$\mathrm{C}(15)-\mathrm{C}(14)$ & $\mathrm{C}(26)$ & $\mathrm{C}(26)-\mathrm{C}(21)$ & $\mathrm{C}(21)-\mathrm{C}(20)$ & $\mathrm{C}(20)-\mathrm{C}(15)$ & $1.464(8)$ \\
$\mathrm{Zn}\left(\mathrm{C}_{13} \mathrm{H}_{9}\right)_{2}{ }^{b}$ & $\mathrm{I}$ & $1.473(9)$ & $1.418(8)$ & $1.444(8)$ & $1.419(81)$ & $1.477(8)$ \\
$\mathrm{Zn}\left(\mathrm{C}_{13} \mathrm{H}_{9}\right)_{2}{ }^{b}$ & $\mathrm{II}$ & $1.460(8)$ & $1.414(8)$ & $1.453(8)$ & $1.420(7)$ & 1.401 \\
$\mathrm{~K}\left(\mathrm{C}_{13} \mathrm{H}_{9}\right)$ & & 1.410 & 1.432 & 1.417 & 1.419 & $(1.504)$ \\
$\mathrm{C}_{13} \mathrm{H}_{10}$ & & 1.504 & 1.398 & 1.491 & $(1.398)$ & \\
\hline
\end{tabular}

\begin{tabular}{ccccccc}
\hline & & \multicolumn{3}{c}{ angles $(\mathrm{deg})$ within the five-membered ring at the indicated $\mathrm{C}$ atom } \\
\cline { 4 - 7 } compd & ring & $\mathrm{C}(1) / \mathrm{C}(14)$ & $\mathrm{C}(2) / \mathrm{C}(15)$ & $\mathrm{C}(7) / \mathrm{C}(20)$ & $\mathrm{C}(8) / \mathrm{C}(21)$ & $\mathrm{C}(13) / \mathrm{C}(26)$ \\
\hline $\mathrm{Zn}\left(\mathrm{C}_{13} \mathrm{H}_{9}\right)_{2}$ & I & $103.7(5)$ & $109.5(5)$ & $108.7(5)$ & $106.8(5)$ & $110.9(5)$ \\
$\mathrm{Zn}\left(\mathrm{C}_{13} \mathrm{H}_{9}\right)_{2}$ & II & $104.1(4)$ & $109.4(5)$ & $107.9(5)$ & $107.6(5)$ & $110.5(6)$ \\
$\mathrm{K}\left(\mathrm{C}_{13} \mathrm{H}_{9}\right)$ & & 108.4 & 107.8 & 107.6 & 107.7 & 108.6 \\
$\mathrm{C}_{13} \mathrm{H}_{10}$ & & 102.7 & 110.8 & 107.9 & $(107.9)$ & $(110.8)$
\end{tabular}

${ }^{a}$ Ring numbering is based on Figure 2. ${ }^{b} \mathrm{C}_{13} \mathrm{H}_{9}=$ fluorenyl.

of 2.041 (5) $\AA$ to $\mathrm{C}(1)$ (of fluorenyl ligand I) and 2.053 (6) $\AA$ to C(14) (of fluorenyl ligand II) are normal for covalent $\mathrm{Zn}-\mathrm{C}$ bonds.

The shortest of the other $\mathrm{Zn}-\mathrm{C}$ separations are clearly nonbonding, i.e. 2.915 (5) $\AA$ to $C(13)$ of ligand I and 2.729 (6) $\AA$ to $C(26)$ of ligand II. The large ring slippage of both five-membered rings of 2.360 and $1.711 \AA$, respectively, is also well in accord with $\eta^{1}$ bonding. (The ring slippage is defined as the distance between the ring centroid and the perpendicular projection of the metal atom on the leastsquares ring plane.)

The bond lengths and bond angles of both five-membered rings show a relatively large alternation (comparable to those in fluorene itself);2 this suggests a predominantly covalent character of the zinc-fluorenyl bond. The alternative, an ionic interaction, should give rise to a far more symmetrical five-membered ring as is found in fluorenylpotassium (Table V).

In each fluorenyl group all five- and six-membered rings themselves are flat within the esd. The dihedral angles between the planes determined by the benzene rings and the five-membered ring and between both benzene rings are small (Figure 5) when compared to those in other known fluorenyl-containing organometallic compounds. ${ }^{2-4,23-25}$

The bond lengths and bond angles of the benzene fragments are similar to those in other known fluorenyl compounds. Comparison of the angles between the zinccarbon bond and the plane of the five-membered ring of the two fluorenyl ligands shows a striking difference. With ligand I the angle of $57.5(3)^{\circ}$ is in good agreement with a covalent zinc-carbon interaction, i.e. half the tetrahedral value of $109.8^{\circ}$, while with ligand II the angle is $77.3(3)^{\circ}$ and closely resembles that found for the $\eta^{1}$-bonded rings in gaseous $\mathrm{Zn}\left(\mathrm{C}_{5} \mathrm{Me}_{5}\right)_{2}$ and in solid $\mathrm{CdCp}_{2} \cdot 2 \mathrm{py}$. The latter two compounds contain metal-cyclopentadienyl bonds, which on the basis of crystallographic and gas phase electron diffraction data were found to be of predominantly ionic character. ${ }^{7-9}$ The reason why the angle with ligand II is distorted almost $20^{\circ}$ from its covalent value may be explained by inter- and intramolecular ring-ring interactions between the aromatic rings of the fluorenyl ligands. From the representation of the unit cell and from Figure 5 it can be clearly seen that the fluorenyl rings within each

(22) (a) Belsky, V. R.; Zavadnik, V. E.; Vozhennikov, Y. M. Acto Crystallogr. 1984, C40, 1220. (b) Gerkin, R. E.; Lundsteal, A. P.; Reppart, W. J. Ibid. 1984, C40, 1892

(23) Kowale, C.; Wunderlich, J. A. Acta Crystallogr. 1976, B32, 820. (24) Treichel, P. M.; Fivizzani, K. P.; Haller, K. J. Organometallics $1982,1,931$.

(25) Ustynyuk, N. A.; Novikova, L. N.; Bel'skii, Y. K.; Oprunenko, Yu. F.; Malyugina, S. G.; Trifonova, O. I.; Ustynyuk, Yu. A. J. Organomet. Chem. 1985, 294, 31 .

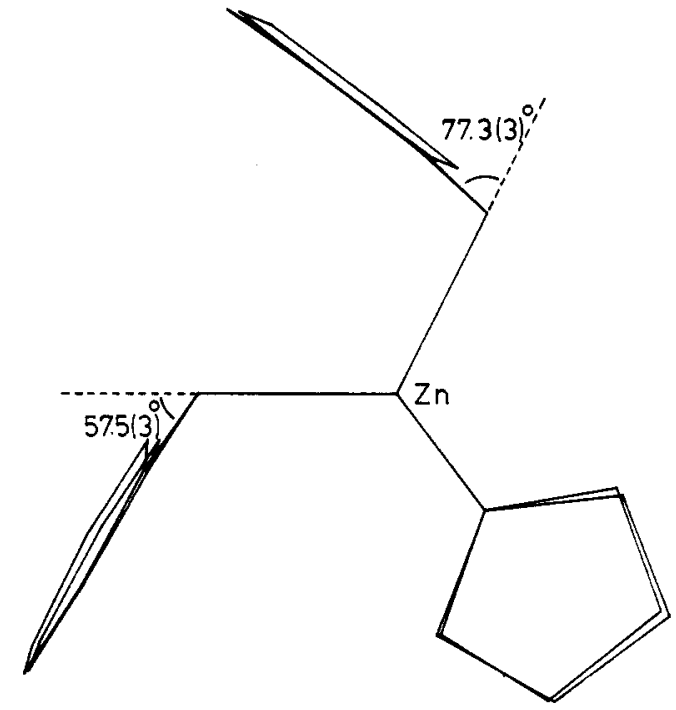

Figure 5. View of the molecule, perpendicular to the plane determined by $\mathrm{Zn}, \mathrm{C} 1$, and $\mathrm{C} 14$, showing the angles between the ring planes and the zinc-carbon bonds and the orthogonality of the fluorenyl ligands.

molecule are mutually orthogonal. Furthermore, although there are no unusually short intermolecular contacts, the crystal packing shows the intermolecular arrangement of most fluorenyl rings to be mutually perpendicular. Although at first sight this might seem surprising, the same perpendicular arrangements of ring systems have also been found in the crystal structure of aromatic compounds like benzene ${ }^{26}$ and in solid fluorene. ${ }^{22}$ Recent results from ab initio calculations, ${ }^{27}$ MM2/MMP2 calculations corrected for electrostatic interactions, ${ }^{28}$ and MM3 calculations ${ }^{29}$ carried out for different benzene dimers as well as for crystalline benzene have shown the minimal energy arrangement to be perpendicular. It appears that in contrast to a "stacked" arrangement of the rings in which only van der Waals forces can play a role, the energy gain in such an orthogonal arrangement can be attributed to the additional electrostatic interactions between the partially positively charged hydrogen atoms and the partially negatively charged carbon atoms. In the solid-state structure of difluorenylzinc the energy gain by this type of interaction of the benzene rings of the fluorenyl ligands may well offset the relative small increase in energy necessary

(26) Cox, E. G.; Cruickshank, D. N. J.; Smith, J. A. S. Proc. R. Soc. London 1964, A279, 98.

(27) Karlström, G.; Linse, P.; Wallquist, A.; Jöhnsson, B. J. Am. Chem. Soc. 1983, 105, 3777 .

(28) Pettersson, I.; Liljefors, T. J. Comput. Chem. 1987, 8, 1139

(29) Allinger, N. L.; Lii, J.-H. J. Comput. Chem. 1987, 8, 1147. 
for the distortion of the bonding angle of fluorenyl ring II with zinc. The shortest intramolecular interligand $\mathrm{C}-\mathrm{C}$ separations are 4.064 (10) $\AA$ between $C(3)$ and $C(16)$ and 4.116 (10) $\AA$ between $\mathrm{C}(3)$ and $\mathrm{C}(17)$. The shortest intermolecular $\mathrm{C}-\mathrm{C}$ distances of perpendicular rings are 3.589 (9) $\AA$ between $C(6)$ and $C(19)$ and 3.685 (9) $\AA$ between $C(6)$ and $C(18)$. These values are in good agreement with those found in solid benzene, i.e. a center-center separation of $5.1 \AA . .^{26}$

Acknowledgment. D. M. Grove is kindly acknowledged for his interest and for his very helpful discussions during the preparation of the manuscript. X-ray data were kindly collected by A. J. M. Duisenberg. This work was supported in part (W.J.J.S. and A.L.S.) by the Netherlands Foundation for Chemical Research (SON) with financial aid from the Netherlands Organization for Scientific Research (NWO).

Registry No. $\mathrm{Zn}\left(\mathrm{C}_{5} \mathrm{H}_{5}\right)_{2}, 11077-31-9 ; \mathrm{Zn}\left(\mathrm{C}_{9} \mathrm{H}_{7}\right)_{2}, 117958-66-4$; $\left(\mathrm{C}_{9} \mathrm{H}_{7}\right) \mathrm{K}, 12128-56-2 ; \mathrm{Zn}\left(\mathrm{C}_{13} \mathrm{H}_{9}\right)_{2}, 117958-67-5 ;\left(\mathrm{C}_{13} \mathrm{H}_{9}\right) \mathrm{Na}, 3531-$ 83-7; $\mathrm{C}_{9} \mathrm{H}_{8}, 95-13-6 ; \mathrm{C}_{13} \mathrm{H}_{10}, 86-73-7 ; \mathrm{ZnCl}_{2}, 7646-85-7 ; \mathrm{Zn}\left(\mathrm{C}_{13^{-}}\right.$ $\left.\mathrm{H}_{9}\right)_{2}(\mathrm{THF})_{2}, 117958-68-6$.

Supplementary Material Available: Tables of anisotropic thermal parameters, all $\mathrm{H}$-atom parameters, bond lengths, and bond angles ( 6 pages); a listing of observed and calculated structure factor amplitudes (24 pages). Ordering information is given on any current masthead page.

\title{
EPR Studies of the Paramagnetic Complexes Produced in the Photochemical Reactions of Hexacarbonylbis $\left(\eta^{5}-2,4-c y c l o p e n t a d i e n-1-y l\right)$ dimolybdenum, $\left[\mathrm{CpMo}(\mathrm{CO})_{3}\right]_{2}$, with $p$-Benzoquinones
}

\author{
Minoru Hanaya ${ }^{1}$ and Masamoto Iwaizumi*,1 \\ Chemical Research Institute of Non-Aqueous Solutions, Tohoku University, Katahira, Sendai 980, Japan
}

Received June 7, 1988

\begin{abstract}
The photochemical reactions of hexacarbonylbis $\left(\eta^{5}-2,4\right.$-cyclopentadien-1-yl)dimolybdenum, $\left[\mathrm{CpMo}(\mathrm{CO})_{3}\right]_{2}$, with a series of $p$-benzoquinones and the structure of the paramagnetic reaction products have been investigated by the EPR spectroscopy. The paramagnetic products can be assigned to complexes of the form of $\mathrm{CpMo}(\mathrm{CO})_{3}\left(p\right.$-benzoquinone), where $\mathrm{CpMo}(\mathrm{CO})_{3}$ produced by photocleavage of the Mo-Mo bond in $\left[\mathrm{CpMo}(\mathrm{CO})_{3}\right]_{2}$ is coordinated by the carbonyl oxygen in the $p$-benzoquinones; the $p$-benzoquinones trap $\mathrm{CpMo}(\mathrm{CO})_{3}$ as monodentate ligands, yielding the paramagnetic complexes. From the $g$ and hyperfine (hf) coupling values of the complexes, the unpaired electron is considered to be mostly on the benzoquinone ligand. At temperatures around $-40^{\circ} \mathrm{C}$, the $p$-benzoquinone ligands show hf couplings symmetrical about the axis connecting their two $\mathrm{C}-\mathrm{O}$ bonds, but at lower temperatures near $-90^{\circ} \mathrm{C}$, the line-width alternation effect is observed in the $\mathrm{hf}$ lines due to the protons at the positions meta to the coordinating carbonyl oxygen; the paramagnetic complex has a $C_{s}$ symmetry as a "time average", and the $p$-benzoquinone ligands are rapidly rotating about the $\mathrm{C}-\mathrm{O}(-\mathrm{Mo})$ bond at most of the temperatures studied.
\end{abstract}

\section{Introduction}

The chemical reactivity of metal carbonyl complexes containing a metal-metal bond has been the subject of extensive study. It has been shown that photolytic cleavage of the metal-metal bonds commonly occurs and the resulting paramagnetic species undergo various reactions. ${ }^{2-5}$ In the previous paper we have shown that the photochemical reactions of hexacarbonylbis $\left(\eta^{5}-2,4\right.$-cyclopentadien-1-yl)dimolybdenum, $\left[\mathrm{CpMo}(\mathrm{CO})_{3}\right]_{2}$, with a series of 0 -quinones and 1,2-diketones give the paramagnetic chelate complexes of $o$-quinones (or 1,2-diketones) and $\mathrm{CpMo}(\mathrm{CO})_{2 \cdot}{ }^{6}$ The chelate complexes were thought to be formed by coordination of the 0 -quinones or 1,2-diketones to $\mathrm{CpMo}(\mathrm{CO})_{3}$, which was produced by photocleavage of the $\mathrm{Mo}-\mathrm{Mo}$ bond of $\left[\mathrm{CpMo}(\mathrm{CO})_{3}\right]_{2}$ followed by elimination

(1) Chemical Research Institute of Non-Aqueous Solutions, Tohoku University.

(2) Geoffroy, G. L.; Wrighton, M. S. Organometallic Photochemistry; Academic: New York, 1979.

(3) Geoffroy, G. L. J. Chem. Educ. 1983, 60, 861.

(4) Meyer, T. J.; Caspar, J. V. Chem. Rev. 1985, 85, 187

(5) Stiegman, A. E.; Tyler, D. R. Coord. Chem. Rev. 1985, 63, 217

(6) Hanaya, M.; Tero-Kubota, S.; Iwaizumi, M. Organometallics 1988 ,

7,1500 . of one of the $\mathrm{CO}$ groups and then the formation of the chelate structure.

On the other hand, it has been shown that $p$-benzoquinones coordinate to the metal by one of their carbonyl oxygens in the complexes of group IVB organometallics 7,8 and some transition metals. ${ }^{9-12}$ However, in studies of the photochemical reaction of $\mathrm{Mn}_{2}(\mathrm{CO})_{10}$ with $p$-benzoquinones, ${ }^{13,14}$ Foster et al. have postulated the formation of the paramagnetic complexes in which $p$-benzoquinones bind to $\mathrm{Mn}(\mathrm{CO})_{5}$ by their quinoid $\pi$ systems, forming a carbon-manganese bond. ${ }^{13}$ In connection with these metal complexes of $p$-benzoquinones and the photochemical reactions of $\left[\mathrm{CpMo}(\mathrm{CO})_{3}\right]_{2}$ with

(7) Alberti, A.; Hudson, A. J. Chem. Soc., Perkin Trans. 2 1978, 1098. (8) Chen, K. S.; Foster, T,; Wan, J. K. S. J. Chem. Soc., Perkin Trans. 21979,1288 75 .

(10) Vlček, A., Jr.; Klima, J.; Vlček, A. A. Inorg. Chim. Acta 1983, 69, 191.

(11) Tuchagues, J.-P. M.; Hendrickson, D. N. Inorg. Chem. 1983, 22, 2545.

(12) Vlček, A., Jr. J. Organomet. Chem. 1985, 297, 43.

(13) Foster, T.; Chen, K. S.; Wan, J. K. S. J. Organomet. Chem. 1980 , $184,113$.

(14) Vlček, A., Jr. J. Organomet. Chem. 1986, 306, 63. 